\title{
O Padroado Régio no Brasil e as Circunscrições Eclesiásticas
}

\author{
Orientador: Luís Corrêa Lima
}

Mestrando: Eraldo de Souza Leão Filho

Área de Concentração: Teologia Sistemático-Pastoral

Linha de Pesquisa: Religião e Modernidade

Projeto de Pesquisa: História da Igreja e Modernidade: Permanências e Mudanças

O tema da presente pesquisa é "O Padroado Régio no Brasil e as Circunscrições Eclesiásticas”. Está inserida nas atividades de pesquisa do Programa de Pós-Graduação em Teologia da PUC-Rio, área de concentração Teologia Sistemático-Pastoral, linha de pesquisa Religião e Modernidade, projeto de pesquisa História da Igreja e Modernidade: Permanências e Mudanças. O que se pretende - como objetivo principal - é investigar o que foi o Padroado Régio e qual a sua preponderância no Brasil no processo de criação das circunscrições eclesiásticas nos períodos colonial e imperial brasileiros. Nesse sentido, recorrendo primordialmente à documentação oficial coeva, investigar-se-á, por um lado, a origem do Padroado Régio Ultramarino de Portugal e a sua incidência na organização circunscritiva da Igreja Católica no Brasil. Depois, uma vez proclamada a independência brasileira, como o Império do Brasil incorporou esse Padroado transformando-o no chamado Padroado Imperial e como o exercitou no que tange à ampliação do número das circunscrições eclesiásticas brasileiras para a promoção de uma maior eficácia pastoral. Faz parte ainda do escopo da pesquisa a identificação de elementos que desmitifiquem a tendência diacrônica relativa à compreensão do Padroado Régio vigente em parte da historiografia moderna, estabelecendo a partir da investigação dos documentos oficiais da época uma distinção entre a essência e a natureza do referido Padroado e as contradições relativas à sua dinâmica e ao seu exercício manifestadas ao longo da história.

Palavras-chave: História da Igreja. Cristandade. Brasil Colônia. Brasil Império. Bulas Papais. 